\title{
Portugal has had in the last months several changes in Labour Law in different areas
}

\section{Teresa Coelho Moreira}

\section{(2) OpenEdition \\ 1 Journals}

\section{Electronic version}

URL: https://journals.openedition.org/rdctss/922

DOI: $10.4000 /$ rdctss.922

ISSN: 2262-9815

\section{Publisher}

Centre de droit comparé du travail et de la sécurité sociale

\section{Printed version}

Date of publication: 1 December 2020

Number of pages: 198-199

ISSN: $2117-4350$

\section{Electronic reference}

Teresa Coelho Moreira, "Portugal has had in the last months several changes in Labour Law in different areas", Revue de droit comparé du travail et de la sécurité sociale [Online], 4 | 2020, Online since 01 December 2020, connection on 26 January 2022. URL: http://journals.openedition.org/rdctss/922 ; DOI: https://doi.org/10.4000/rdctss.922

\section{(c) $(1) \odot \odot$}

Revue de droit comparé du travail et de la sécurité sociale est mise à disposition selon les termes de la Licence Creative Commons Attribution - Pas d'Utilisation Commerciale - Pas de Modification 4.0 International. 


\section{TERESA COELHO MOREIRA}

UNIVERSITY OF MINHO, SCHOOL OF LAW

\section{PORTUGAL HAS HAD IN THE LAST MONTHS SEVERAL CHANGES IN LABOUR LAW IN DIFFERENT AREAS}

\section{I - THE INCREASE IN THE MINIMUM WAGE}

In January 2020 the minimum wage was increased to 635 euros per month, and it was implemented on 1 January 2020 by Decree-Law no. 167/2019 of 21 November.

The aim of the new Government is to reach 750 Euros in 2023. Article 273, no. 1, of Portuguese Labour Code guarantees all employees a minimum monthly wage, to be annually established by specific legislation, following consultation of the social partners because this topic requires a binding opinion by the Standing Committee for Social Concertation (CPCS).

This year the decision on increasing the minimum wage was adopted without the tripartite agreement.

\section{II - AMENDMENTS ON PORTUGUESE LABOUR CODE AND CONSTITUTIONAL COURT}

On 4 September the Law 93/2019, amended the Labour Code in several aspects, that enter into force on 1 October 2019. This Law was approved after many discussions in the Parliament and the final text was only approved in July.

However, there are different periods for some of the amendments.

The legislation introduces an excessive turnover fee that should take effect on 1 January 2020. However companies will only start to pay the fee in 2021 because its implementation depends on provisions to determine the sector average turnover, related to 2020, which will serve as a reference. The fee will be applied when companies exceed the average number of fixed-term contracts in each sector. The Government said that is going to present in the Standing Committee for Social Concertation a proposal on that topic.

Individual working time accounts - which allow negotiations to take place between employer and employee, bypassing collective agreements - that are currently in place because they started before the new legislation entered into force, cease within one year of the entry into force of the amendments to the Labour Code. As of that date, no individual working time account can be in operation. 
Nevertheless, three parties - The Left Bloc, the Portuguese Communist Party and The Greens - asked the Constitutional Court to review some of the Labour Code amendments on the grounds that they violate the principles of fairness, equality - article 13 of the Portuguese Constitution -, and Security at Work that is established in article 53 of the Portuguese Constitution. The amendments were these: the extension of the normal probation period from 90 to 180 days when hiring first-time jobseekers and those who have been unemployed for a significant period of time; and increasing the duration of very shortterm contracts from 15 days to 35 days, and allowing their use beyond seasonal activities in the agriculture and tourism sectors. They also asked the court to review the provisions that introduced the possibility of terminating collective agreements when a signatory organisation ceases to exist, whether employer organisation or trade union, because they defend that is a violation of constitutional rights regarding collective bargaining.

\section{II - NEW RIGHTS ON PARENTAL LEAVE AND A NEW LAW ABOUT INFORMAL CARERS}

On 4 September was approved Law no. 90/2019 that wants to reinforce the rights of the parents and that also makes amendments to the Labour Law Code.

Related with parental leave, there was an extension on the fathers' mandatory leave, from 15 working days to 20 working days, to be used within six weeks of the birth of a child. The mothers' mandatory leave is of sex weeks and remained the same. Five of these days must be used immediately after the child's birth.

Additionally, after this leave, fathers can have more five working days of leave, as long as it occurs at the same time as the mother's initial parental leave.

There were also measures to assure a special leave when parents have a child with an oncological disease and also some protection establishing a specific regime of absences for medically assisted procreation and establishing that the workers' absence doesn't produce any loss of rights.

On 6 September was approved Law no. 100/2019 about informal carers that defines the status of an informal carer and regulates the rights and obligations of the same and the person being cared for, and establishes the respective support measures. 